\title{
Application of Guided Inquiry Learning Model with Mind Map toward Students' Learning Outcomes in Chemistry Material: Reaction Rate
}

\author{
Purnama Ningsih \\ Universitas Tadulako \\ Palu, Indonesia \\ purnamaningsih@yahoo.com
}

\author{
Irwan Said \\ Universitas Tadulako \\ Palu, Indonesia
}

\begin{abstract}
This study examined the differences in students' learning outcomes in chemistry material: reaction rate between an experiment group (using guided inquiry learning model with mind map) with a controll group (using group discussion with students' worksheet) in SMA Labschool Palu. This research was a quasi-experimental research with a non-randomized pretestposttest control group. The sample in this study was taken using purposive sampling technique then resulting class XI IPA 1 as the experiment group and class XI IPA 2 as the control group. Data was analyzed using t-test one tail and effect size test. The result of this study showed that there is a difference in students' learning outcomes between the experimental group and the control group, where students were taught by the guided inquiry learning model with mind map got high scores compared to students were taught by a group discussion with students' worksheet. Furthermore, the study also showed that the effect size is in category "medium".
\end{abstract}

\section{Keywords—guided inquiry; mind map; learning outcomes}

\section{INTRODUCTION}

Literally, chemistry is the study of matter and its properties, how and why substances combine or separate to form other substances, and how substances interact with energy. Therefore, in learning chemistry, it is not enough if just taught by the simple way which is providing the meanings, facts, concepts, principles, but also by discovering through the process of seeking by real action (inquiry) [1]. Many concepts in chemistry are abstract and interrelated, including the reaction rate. Studying the concept of reaction rate requires conceptual understanding. According to Wiyatsih [2], due to in reaction rate's material is abstract, by choosing a model that involves the students' activity in finding the concepts is appropriate. The learning model can be used in this case is the guided inquiry learning model.

The guided inquiry learning model is a learning model that has a number of steps, to solve problems, make experiments plan, conduct experiments, collect data, analyze data, and make conclusions. According to Alberta, the guided inquiry learning model consists of six syntaxs [3] as follows:

\section{1) Planning.}

In the first syntax, teachers give problems related to daily life. Besides that, teachers also present the procedure to solve the problems to students. So they can find the solution through experiment work.

\section{2) Retrieving.}

In this part, students have a job to find and collect data about the problems that gave by teachers from various sources.

\section{3) Processing information.}

Students do the test and prove the hypothesis by conducting experiments. The also do analyze in this step.

\section{4) Making/Creating information.}

In this syntax, students make decisions and conclusions from their works above.

\section{5) Communicating/sharing information.}

Students present their result by discussion in class, while teachers make comments on this discussion and provide reinforcement and straighten mistakes.

\section{6) Evaluating.}

In this last syntax, teachers award each of the groups who have made presentations and then they provide authentic individual tasks regarding with the materials that have been studied.

The process in this model, students are involved mentally and physically in solving problems that given by the teacher. Students will be accustomed to behaving like a scientist, which is objective, creative, and respect the opinions of others [4].

A mind map is a technique of summarizing the material to be studied and projecting the problems faced into the form of maps or graphics techniques so that it is easier to understand. Learning processes by using mind map will improve the memory and motivation of strong student learning, and students become more creative [5]. In addition to teaching and learning activities, it will be more interesting where students will also be more motivated by learning chemistry. 
Learning outcomes are a change in student behavior due to the learning process. Behavior changes are caused by students achieve mastery over a number of materials provided in teaching and learning process. There are three skills in learning outcomes, cognitive, affective, and psychomotor. These skills are obtained through teaching and learning process [6].

For comparison, a group discussion method with students' worksheet was also applied in this study. Group discussion is part of the discussion method. The way the delivering subject material is conducted by giving the students the opportunity to collect opinions, make conclusions or arrange various alternative problem-solving. Problems relating to the subject matter can become from students or given by teachers. A student worksheet is a learning media that can be used in experimental activities, demonstrations, discussions, and can also be used as a guidance when doing tasks [7]. Therefore, by combining between the group discussion method and student worksheet in the learning process, it can be applied as an alternative way to find the students' own concepts through discussion and experience.

This study aimed to examine the differences in students' learning outcomes of the learning process in the classroom using the guided inquiry learning model with mind map with students learning using group discussion method with student worksheet in chemistry material, the reaction rate.

\section{METHOD}

This study was conducted in SMA Labschool Palu. The population of this study was students of class XI that registered in the academic year 2016/2017. Sampling technique was purposive sampling that considered based on the average of the score in chemistry subject in the previous semester, where class XI IPA 1 as the experiment group and class XI IPA 2 as the control group. The instrument used in this study was the written test (multiple choice form), 21 items after validation. The technique of completion of data through 3 steps as follows:

\section{1) The preparation step:}

Observing of the research location, determining the population and the sample of the study, making the written test (before this test was used, it was analyzed to find validity, reliability, difficulty, and distinguishing), making lesson plan based on KTSP Curriculum with time allocation $6 \times 45$ minutes.

\section{2) The implementation step:}

Carrying out pretest prior to the learning process, a learning process that using inquiry-guided learning model with mind map in the experiment group and group discussion method with student worksheet in the control group, after that carrying out posttest on each class.

\section{3) The final step, collecting and analyzing data.}

Data were analyzed with the t-test one tail (hypothesis test). Prior to analysis, data was examined with the prerequisite test (normality test and homogeneity test). Besides that, the effect size test was performed in this study.

\section{RESULTS AND DISCUSSION}

Data were collected in class XI IPA 1 and XI IPA 2 in SMA Labschool Palu. There were 39 students involving in this study. Based on the research result, it was obtained pretest and posttest score of students from the experiment group and the control group as can be seen in Table I.

TABLE I. DATA of ThE PRETEST AND POSTTEST SCORES IN THE EXPERIMENT GROUP AND THE CONTROL GROUP

\begin{tabular}{|l|c|c|c|c|}
\hline & \multicolumn{2}{|c|}{ Experiment Group } & \multicolumn{2}{c|}{ Control Group } \\
\hline & Pretest & Posttest & Pretest & Posttest \\
\hline Number of students & 19 & 19 & 20 & 20 \\
Lowest score & 14 & 30 & 10 & 33 \\
Highest score & 48 & 95 & 48 & 71 \\
Average & 27,79 & 57,61 & 26,90 & 52,10 \\
Deviation Standard & 10,40 & 21,03 & 12,39 & 11,15 \\
\hline
\end{tabular}

As can be seen in Table I, the average scores's pretest of the two groups were not much different. It was indicating that the students' initial ability was same before the learning process took place. According to [8], this situation implies that the two selected groups (experiment and control) were at the same level of achievement before treating different learning acts. However, the average scores' posttest showed different things after the learning process. The average scores' posttest of the experiment group was higher than the average scores of the control group.

To further investigation, whether there were differences in students' learning outcomes between the two groups after learning process by using a different way, an inferential statistical test was used. In this case, we used t-test one tail. Prior to conducting the test, a prerequisite test should be done, namely normality and homogeneity tests. The result of the normality test can be seen in Table II, while the result of the homogeneity test can be seen in Table III.

TABLE II. DATA OF THE NORMALITY TEST

\begin{tabular}{|c|c|c|c|c|}
\hline \multirow{2}{*}{ Group } & \multirow{2}{*}{$\mathbf{N}$} & \multicolumn{3}{|c|}{ Normality Test } \\
\hline & & $X_{\text {count }}^{2}$ & $X_{\text {table }}^{2}$ & Conclusion \\
\hline Experiment & 19 & 5,15 & 5,99 & $\begin{array}{c}\mathrm{X}_{\text {count }}^{2}< \\
\mathrm{X}_{\text {table, }}^{2}\end{array}$ \\
\hline Control & 20 & 4,58 & 5,99 & $\begin{array}{c}\text { data was } \\
\text { normal }\end{array}$ \\
\hline
\end{tabular}

TABLE III. DATA OF THE HOMOgENEITY TEST

\begin{tabular}{|l|c|c|c|c|}
\hline \multirow{2}{*}{ Group } & \multirow{N}{*}{$\mathbf{N}$} & \multicolumn{3}{|c|}{ Homogeneity Test } \\
\cline { 3 - 5 } & & $\boldsymbol{F}_{\text {count }}$ & $\boldsymbol{F}_{\text {table }}$ & Conclusion \\
\hline Experiment & 19 & 1,88 & 2,19 & $\begin{array}{c}\mathrm{F}_{\text {count }}<\mathrm{F}_{\text {table, }} \\
\text { data was } \\
\text { homogen }\end{array}$ \\
\hline
\end{tabular}

The normality test is used to prove whether the samples come from normally distributed populations or not, whereas the homogeneity test is used to prove samples from homogeneous populations or not [9]. Based on Table II and Table III, data from this study were normal and homogenous. 
It means the t-test one tail as hypothesis test can be continued. The result of t-test one tail can be seen in Table IV.

TABLE IV. DATA OF T- TEST ONE TAIL

\begin{tabular}{|c|c|c|l|}
\hline \multirow{2}{*}{ t-test } & $\mathbf{t}_{\text {count }}$ & $\mathbf{t}_{\text {table }}$ & Conclusion \\
\cline { 2 - 4 } & 2,42 & 1,68 & $\mathrm{t}_{\text {count }} \geq \mathrm{t}_{\text {table }}$ \\
\hline
\end{tabular}

Based on the result of hypothesis analysis with the t-test (right side), it was obtained $t_{\text {count }} \geq t_{\text {table }}(2,42 \geq 1.67)$ at $5 \%$ of a significant level. $\mathrm{H}_{0}$ hypothesis was rejected and hypothesis $\mathrm{H}_{1}$ was accepted. This means that the students' learning outcome using the guided inquiry model with mind map was higher than the students' learning outcomes using the group discussion method with students' worksheets on the material reaction rate class XI IPA SMA Labschool Palu. In other words, there are differences in student learning outcomes between the experimental group and the control group.

The students' learning outcomes in the experimental group where higher than the students in the control class, it showed that the guided inquiry model with the mind map has an effect on the students' learning outcomes. The results of this study were then continued with effect size test to determine the effect of the model's use on student learning outcomes. The effect size result was calculated then categorized based on Cohen's interpretation as can be seen in Table V.

TABLE V. THE COHEN'S INTERPRETATION

\begin{tabular}{|c|c|}
\hline $\begin{array}{c}\text { Cohen's } \\
\text { Interpretation }\end{array}$ & Effect Size \\
\hline Large & $0,6-2,0$ \\
Medium & $0,3-0,5$ \\
Small & $0,0-0,2$ \\
\hline
\end{tabular}

The result of effect size's calculation $(\delta)$ was 0,3 . It means in the medium category, so it can be said that applying of the guided inquiry learning model with mind map has the influence of students' learning outcomes. To see the magnitude of the effects caused by each model or method applied in both the experimental group and in the control group on students' learning outcomes was also measured using effect size test. The results can be seen in Table VI.

TABLE VI. DATA OF EFFECT SIZE

\begin{tabular}{|c|c|c|}
\hline \multirow{2}{*}{ Effect Size } & $\begin{array}{c}\text { Experimental } \\
\text { group }\end{array}$ & $\begin{array}{c}\text { Control } \\
\text { Group }\end{array}$ \\
\cline { 2 - 3 } & 1,67 & 1,42 \\
\hline
\end{tabular}

From Table VI, it can be seen that the results show that each model and method (the guided inquiry learning model with a mind map and the group discussion method with students' worksheet) give influence to students' learning outcomes and based on the effect size category, both where in the large category. However, the effect size from the experimental group (1.67) was larger than the control group (1.42). So, it can be said that the learning process of the chemistry material (reaction rate) using the guided inquiry learning model with mind map gives a positive effect on students' learning outcomes.

Based on the data obtained both in the inferential statistical test and the effect size test, the guided inquiry learning model with the mind map has an effect on the students' learning outcomes which resulted in higher scores of students. This is due to the advantages of characterizing the guided inquiry learning model, which can form and develop a "self concept" on the students. So that students can understand the basic concepts and ideas much better. In addition, the advantages of the mind map, which allows students to remember facts, numbers, and formulas easily and quickly. According to [10] in their study, the students' learning outcomes with the application of the guided inquiry learning model on the material of the reduction and oxidation reaction was very good (the average score of students was 3.28 and the classical completeness of the students' learning outcomes was $94,1 \%$ ). Other study showed that results for students' learning outcomes who learn with guided inquiry model where better than students learning with conventional learning models. This is because firstly, the guided inquiry learning model can provide opportunities for students to participate actively in the learning process. After that, students in find concepts that are studied independently based on the problems that exist in the environment. Students will gain more meaningful experience and keep it in their minds then it will certainly have an impact on the acquisition of students' learning outcomes [4].

\section{IV.CONCLUSION}

Based on the results and discussion above, it can be concluded that there is the difference in students' learning outcomes between students were taught by the guided inquiry learning model with mind map with students were taught by a group discussion with student's worksheet. Furthermore, the application of the guided inquiry learning model with mind map has a positive effect of students' learning outcomes.

\section{ACKNOWLEDGMENT}

The authors acknowledge Regina S. Lumentut and Zaitun for their assistance in collecting data. The authors also thank to students and teachers in SMA Labschool Palu.

\section{REFERENCES}

[1] M. Malihah, "Pengaruh model guided inquiry (Inkuiri Terbimbing) terhadap hasil belajar kimia siswa pada konsep laju reaksi (Quisi eksperiment di kelas XI IPA SMAN I Leuwiliang)," 2011.

[2] K. Wiyatsih, "Pengaruh Penerapan Model Pembelajaran Inkuiri Terbimbing terhadap Prestasi dan Motivasi Belajar Siswa Kelas X SMA Negeri 1 Purwosari pada Materi Reaksi Redoks," SKRIPSI Jurusan Kimia-Fakultas MIPA UM, 2011.

[3] L. Alberta, "Focus on Inquiry: a teacher's guide to implementing inquiry based learning," Edmonton, AB: Alberta education, 2004. 
[4] N. Dias and L. Dewi, "Pengaruh Pendekatan Keterampilan Proses Ipa Dan Hasil Belajar Ranah Kognitif Peserta Didik Smp Pendekatan Guided Inquiry Terhadap Keterampilan Proses Ipa Dan Hasil Belajar Ranah Kognitif Peserta Didik Smp Terhadap Keterampilan Proses Ipa Dan Hasil Belajar," Universitas Negeri Yogyakarta, 2012.

[5] T. Buzan, Buku pintar mind map untuk anak: agar anak jadi pintar di sekolah: Gramedia Pustaka Utama, 2007.

[6] M. Y. Mappeasse, "Pengaruh Cara dan Motivasi Belajar Terhadap Hasi Belajar Programmable Logic Controller (PLC) Siswa Kelas III Jurusan Listrik SMK Negeri 5 Makassar," Jurnal Medtek, vol. 1, pp. 7-12, 2009.

[7] S. Budisetyawan, "Pengembangan LKS IPA Terpadu Berbasis Inkuiri Terbimbing pada Tema Sistem Kehidupan dalam Tumbuhan Kelas VIII di SMP N 2 Playen," Jurnal Pendidikan IPA FMIPA UNY, vol. 1, pp. 16, 2012.
[8] P. Parno, "Pengaruh Model Penemuan Terbimbing Dengan Strategi SelfExplanation Terhadap Prestasi Belajar Fisika Zat Padat Mahasiswa," Jurnal Pendidikan Fisika Indonesia, vol. 11, pp. 23-35, 2015.

[9] A. Yudawan, Rubini, B.,\& Kurniasih, S. , " Model pembelajaran problem based learning dan guided discovery learning berbantuan media pembelajaran muvis terhadap literasi sains," PEDAGOGIA Jurnal Ilmiah Pendidikan, vol. 7, pp. 265-273, 2015.

[10] N. Mutrovina and S. H. Syarief, "Meningkatkan Keterampilan Proses Sains Siswa Melalui Penerapan Model Pembelajaran Inkuiri Terbimbing Pada Materi Reaksi Reduksi-Oksidasi Di Kelas X Sma Negeri 12 Surabaya (Increasing The Student Science Prosess Skills With Guided Inquiry Learning Model At Reduction-Oxidation Reaction For X Grade Of 12 Surabaya Senior High School)," UNESA Journal of Chemical Education, vol. 4, 2015 